\title{
Validation of UV-Vis spectrophotometry methode for analysis of apigenin in celery extract (Apium graveolens $\mathbf{L}$.)
}

\section{Validasi metode spektrofotometri UV-Vis untuk analisis apigenin dalam ekstrak seledri (Apium graveolens $\mathbf{L}$.}

\author{
Asep Nurrahman Yulianto ${ }^{* 1}$, Taofik Rusdiana ${ }^{2}$, Muchtaridi' ${ }^{2}$, Anas Subarnas ${ }^{2}$ \\ ${ }^{1}$ Program Studi D3 Farmasi STIKES Al-Irsyad Al-Islamiyyah Cilacap \\ Jl. Cerme No.24 Sidanegara, Cilacap Tengah, Cilacap 53223 \\ ${ }^{2}$ Fakultas Farmasi, Universitas Padjadjaran \\ Jl. Raya Bandung - Sumedang Km 21 Jatinangor, Sumedang 45363
}

\begin{abstract}
ABSTRAK
Apigenin merupakan salah satu senyawa flavonoid yang terkandung dalam seledri (Apium graveolens L.) dan telah banyak dimanfaatkan untuk pengobatan berbagai jenis penyakit. Penelitian ini bertujuan untuk memastikan validitas dan akurasi suatu metode analisis penetapan kadar apigenin dalam ekstrak seledri secara spektrofotometri UV-Vis. Uji flavonoid dalam ekstrak seledri memberikan hasil yang positif menghasilkan warna kuning yang dapat ditarik oleh amil alkohol. Hasil uji KLT menggunakan pengembang kloroform : metanol $(9,5: 0,5)$ menghasilkan nilai $R_{f}$ sebesar 0,75. Parameter validasi metode analisis yang digunakan meliputi sensitivitas, linearitas, batas deteksi, batas kuantifikasi, akurasi, dan presisi. Validasi metode analisis menunjukkan hasil sensitivitas yang diwakilkan oleh ekstingsi molar $(\varepsilon)$ sebesar $77.004,35 \mathrm{M}^{-1} \mathrm{~cm}^{-1}$. Persamaan garis yang dihasilkan dari kurva kalibrasi pada konsentrasi 2, 4, 6, 8, dan $10 \mathrm{mgL}^{-1}$ adalah $y=0,074 x-0,0011$ dengan koefisien korelasi (r) sebesar 0,9996. Nilai batas deteksi dan batas kuantifikasi yang dihasilkan masing-masing sebesar 2,99 $\mathrm{mgL}^{-1}$ dan $9,92 \mathrm{mgL}^{-1}$ dengan persen perolehan kembali sebesar $97,59 \%$ serta persen koefisien variasi untuk uji presisi sebesar $1,53 \% ; 2,43 \%$ dan $1,68 \%$. Rerata kadar apigenin dalam ekstrak seledri yang diperoleh sebesar 3,74 $\pm 0,09 \%$.
\end{abstract}

Kata kunci: seledri, apigenin, Spektrofotometri UV-Vis, validasi

\begin{abstract}
Apigenin is one of the flavonoid compounds contained in celery (Apium graveolens L.) and has been used for the treatment of various diseases. This study aims were to ensure the validity and accuracy of analytical method for apigenin assay in celery extract using UV-Vis spectrophotometry. The flavonoids test of celery extract give a positive result which produces a yellow color that can be drawn by amyl alcohol. The result of TLC test using a mobile phase of chloroform and methanol (9.5 : 0.5 ) produced $R_{f}$ value of 0.75 . Validation of analytical methods were sensitivity, linearity, limit of detection as well as limit of quantification, accuracy, and precision. Validation of analytical methods showed that sensitivity results as represented by molar extinction ( $\left(\right.$ ) was $77004.35 \mathrm{M}^{-1} \mathrm{~cm}^{-1}$.
\end{abstract}

\footnotetext{
Penulis korespondesi:

Asep Nurrahman Yulianto

Program Studi D3 Farmasi STIKES Al-Irsyad Al-Islamiyyah Cilacap

Jl. Cerme No.24 Sidanegara, Cilacap Tengah, Cilacap 53223

Email: nurrahmanasep@yahoo.co.id
} 
Linearity from calibration curve at concentration of $2,4,6,8$, and $10 \mathrm{mgL}^{-1}$ resulted an equation of $y=$ $0.074 x-0.0011$ with coefficient correlation $(\mathrm{r})$ of 0.9996 . The limit of detection and limit of quantification were $2.99 \mathrm{mgL}^{-1}$ and $9.92 \mathrm{mgL}^{-1}$ respectively with recovery percentage of $97.59 \%$ and the coefficient variation values were $1.53 \% ; 2.43 \%$ and $1.68 \%$. The average contents of apigenin in the celery extract were of $3.74 \pm 0.09 \%$.

Keywords: celery, apigenin, UV-Vis Spectrophotometry, validation

\section{PENDAHULUAN}

Seledri atau Apium graveolens L. merupakan salah satu tumbuhan yang banyak digunakan secara tradisional untuk pengobatan berbagai jenis penyakit, diantaranya digunakan sebagai obat hipertensi, diuretik, peluruh batu ginjal, hiperlipidemia, antioksidan, rheumatik, dan antimikroba (Vergara et al., 2013; Andrea et al., 2013; BPOM RI, 2008; Ellin et al., 2009; Arzi et al., 2014). Komponen metabolit sekunder yang terdapat dalam seledri salah satunya adalah apigenin (Agoes, 2010; Al-snafi, 2014).

Apigenin (4',5,7-trihydroxyflavone, $\left.\mathrm{C}_{15} \mathrm{H}_{10} \mathrm{O}_{5}\right)$ merupakan flavonoid dari sayur dan buah. Gambar 1 merupakan struktur dari apigenin, yang memiliki bobot molekul 270,23 g/moL dan titik leleh $345-350^{\circ} \mathrm{C}$. Dibandingkan dengan flavonoid lainnya seperti quercetin, apigenin relatif tidak beracun dan nonmutagenik (Boyong et al., 1997). Senyawa ini besifat vasodilator atau vasorelaksator dan berfungsi sebagai antihipertensi, antikanker serta anti asam urat (Choi \& Kim, 2009; Shukla \& Gupta, 2008).

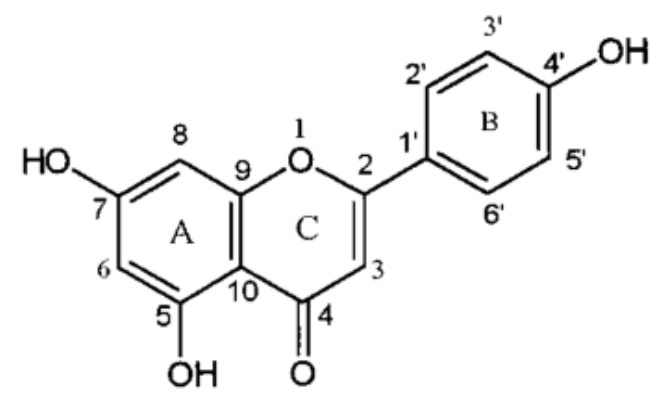

Gambar 1. Struktur apigenin (Boyong et al., 1997).

Analisis penetapan kadar apigenin dalam ekstrak seledri pada penelitian ini menggunakan Spektrofotometri UV-Vis. Metode penetapan kadar zat menggunakan spektrofotometri UV-Vis adalah salah satu metode yang paling sering digunakan dalam analisis farmasi karena metode ini yang sederhana, cepat, cukup spesifik dan bisa digunakan untuk suatu senyawa dalam jumlah yang kecil (Siladitya et al., 2012).

Sama halnya dengan golongan flavonoid lainnya, apigenin juga memiliki dua puncak serapan utama. Satu di $340 \mathrm{~nm}$ (cincin B+C; 300-380 nm; grup cinnamoyl) dan satu lagi di $269 \mathrm{~nm}$ (cincin $\mathrm{A}+\mathrm{C}$; 240-280 nm; grup benzoyl; Gambar 1). Umumnya, puncak serapan yang dihasilkan dapat memberikan informasi tentang pola substitusi flavonoid (Zsófia et al., 2016).

Sebelum melakukan metode analisis, dilakukan validasi metode terlebih dahulu untuk memastikan suatu metode analisis yang digunakan memberikan hasil analisis yang valid dan akurat (Hidayat, 1999). Validasi metode merupakan upaya untuk mengevaluasi dan mendokumentasi bukti dari suatu prosedur layak digunakan dan memberikan hasil yang dapat dibandingkan. Suatu hasil metode analisis dapat digunakan apabila memenuhi parameter yang telah ditentukan (Siladitya et al., 2012). Parameter validasi ini meliputi sensitivitas, linearitas, batas deteksi, batas kuantifikasi, akurasi, dan presisi.

Penelitian ini bertujuan untuk mendapatkan metode yang valid dan akurat dalam penetapan kadar apigenin menggunakan spektrofotometri UV-Vis. Selama ini belum pernah dilaporkan 
penelitian mengenai validasi metode analisis apigenin menggunakan spektrofotometri UV-Vis. Untuk meningkatkan keakuratan dan kevalidan dari suatu metode analisis menggunakan spektrofotometri UV-Vis, parameter akurasi dan presisi merupakan parameter yang tepat untuk dilakukan karena parameter ini menggunakan standar apigenin yang ditambahkan kedalam sampel ekstrak seledri (standart addition). Sehingga diharapkan dengan penambahan standar apigenin kedalam sampel, akan lebih menguatkan keberadaan senyawa apigenin dalam sampel ekstrak seledri.

\section{METODE PENELITIAN}

\section{Alat dan Bahan}

Alat yang digunakan adalah spektrofotometri UV-Vis (Analytic Jena Specord 200) dan ultrasonic sonicator. Bahan yang digunakan adalah Seledri (Apium graveolens L.) diperoleh dari Ciwidey, Jawa Barat. Apigenin standar diperoleh dari Chengdu Biopurity Phytochemicals, China (purity 98\%). Etanol 96\%, metanol, kloroform, dan aquadest diperoleh dari PT Graha Jaya Pratama Kinerja, Indonesia.

\section{Jalannya Penelitian \\ Pembuatan ekstrak seledri}

Ekstraksi dilakukan secara maserasi dengan menambahkan pelarut etanol 96\% sebanyak 20 liter ke dalam 3,4 kg simplisia seledri yang telah dihaluskan, lalu diamkan selama 3x24 jam. Ekstrak kemudian disaring dan dipekatkan menggunakan evaporator. Ekstrak kental kemudian di freeze dry untuk mendapatan ekstrak yang lebih kering.

\section{Uji flavonoid}

Sebanyak $100 \mathrm{mg}$ ekstrak seledri dalam tabung reaksi dilarutkan dalam $20 \mathrm{~mL}$ air. Larutan ekstrak dipanaskan diatas penangas air selama 30 menit. Larutan kemudian ditambahkan serbuk magnesium sebanyak $5 \mathrm{mg}$ dan ditetesi asam klorida $2 \mathrm{~N}$ sebanyak 5 tetes. Sebanyak $10 \mathrm{~mL}$ amil alkohol ditambahkan kedalam campuran tersebut lalu dikocok kuat-kuat. Terbentuknya warna kuning hingga merah yang dapat ditarik oleh amil alkohol menunjukkan adanya flavonoid (Harborne, 1987).

\section{Analisis Apigenin Menggunakan Kromatografi Lapis Tipis (KLT)}

Pada lempeng silika gel $\mathrm{GF}_{254}$ ditotolkan ekstrak dan Apigenin Standar. Fase gerak yang digunakan adalah kloroform : metanol $(9,5: 0,5)$. Lempeng silika gel dimasukkan ke dalam chamber yang berisi fase gerak yang telah dijenuhkan. Lempeng dikeringkan dan dilihat penampang bercaknya dibawah sinar UV 254 dan $365 \mathrm{~nm}$ (Rahma, 2008).

\section{Pembuatan larutan apigenin standar $\left(100 \mathrm{mgL}^{-1}\right)$}

Larutan stok apigenin dibuat dengan cara melarutkan $10 \mathrm{mg}$ serbuk apigenin standar dalam 50 $\mathrm{mL}$ etanol 96\% dalam labu ukur $100 \mathrm{~mL}$. Larutan disonikasi menggunakan ultrasonicator selama 10 menit hingga melarut sempurna. Tambahkan etanol 96\% hingga tanda batas (Vidya et al., 2011).

\section{Pembuatan larutan sampel ekstrak seledri $\left(1000 \mathrm{mgL}^{-1}\right)$}

Sebanyak 100 mg ekstrak seledri dilarutkan dalam 50 mL etanol 96\% dalam labu ukur $100 \mathrm{~mL}$. Larutan disonikasi menggunakan ultrasonicator selama 30 menit. Tambahkan etanol $96 \%$ hingga tanda batas labu. Larutan kemudian disaring menggunakan kertas saring whatman No. 41 (Vidya et al., 2011).

\section{Penentuan panjang gelombang serapan maksimum $(\lambda \max )$ apigenin}

Dilakukan pengenceran larutan baku standar menjadi $10 \mathrm{mgL}^{-1}$ dalam labu ukur $20 \mathrm{~mL}$. Hasil pengenceran diukur profil absorbansinya pada panjang gelombang 200-400 $\mathrm{nm}$. Pengukuran dilakukan sebanyak 5 kali pengulangan dalam hari yang sama. 


\section{Validasi Metode Analisis}

\section{Sensitivitas}

Parameter sensitivitas dapat ditentukan dengan menghitung ekstingsi molar $(\varepsilon)$ larutan Apigenin Standar. Larutan baku standar diencerkan hingga didapatkan konsentrasi akhir 4, 6, dan $8 \mathrm{mgL}^{-1}$. Ketiga larutan tersebut kemudian dianalisis dengan spektrofotometri UV-Vis dan diukur absorbansinya pada panjang gelombang $269 \mathrm{~nm}$ ( $\lambda$ max apigenin). Nilai ekstingsi molar dapat ditentukan menggunakan persamaan :

$$
\varepsilon=\frac{A}{B \cdot C}
$$

Keterangan :

A : absortivitas molar (A)

B : tebal kuvet $(\mathrm{cm})$

$\mathrm{C}$ : konsentrasi apigenin (Molar)

\section{Linearitas}

Kurva baku apigenin dibuat dengan mengencerkan larutan baku standar menjadi 2, 4, 6, 8, dan $10 \mathrm{mgL}^{-1}$. Masing-masing larutan diukur absorbansinya pada panjang gelombang $269 \mathrm{~nm}$, dilakukan sebanyak tiga kali pengulangan. Dari hasil absorbansi yang didapat kemudian diplotkan kedalam persamaan garis $(y=a x+b)$. Linearitas didapatkan dari koefisien korelasi $(r)$.

\section{Batas deteksi dan batas kuantifikasi}

Batas deteksi dan batas kuantifikasi didapatkan dari persamaan linear kurva kalibrasi.

Batas deteksi dan batas kuantifikasi dinyatakan dengan rumus :

$$
L O D=3,3 \frac{S a}{5} ; L O Q=10 \frac{S a}{5}
$$

Keterangan :

LOD : Batas deteksi

LOQ : Batas kuantifikasi

$\mathrm{Sa} \quad$ : Intersep simpangan baku

$\bar{b} \quad$ : Rata-rata kemiringan garis

\section{Akurasi dan presisi}

Akurasi dan presisi dalam metode ini menggunakan metode penambahan standar kedalam ekstrak seledri. Sebanyak $4 \mathrm{~mL}$ larutan baku ekstrak seledri dimasukkan kedalam labu ukur $20 \mathrm{~mL}$ dan masing-masing sebanyak 0,8; 1,2; dan 1,6 mL larutan baku standar ditambahkan kedalam labu ukur tersebut. Tambahkan etanol $96 \%$ hingga batas labu.

Persen perolehan kembali dihitung dengan rumus :

$$
(\% P K)=\frac{a-b}{c} \times 100 \%
$$

Keterangan :

PK : perolehan kembali

a : konsentrasi sampel + standar

b : konsentrasi sampel

c : konsentrasi standar teoritis yang ditambahkan

Presisi menunjukkan rentang nilai taksiran yang dianggap memenuhi kriteria analisis pengukuran. Nilai presisi didapatkan dari nilai KV (\%) yang ditentukan dengan rumus : 


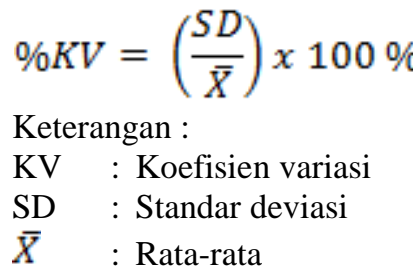

\section{Uji kadar apigenin dalam ekstrak seledri}

Sebanyak $4 \mathrm{~mL}$ larutan ekstrak seledri yang sudah dibuat dengan konsentrasi $1000 \mathrm{mgL}^{-1}$, dimasukkan kedalam labu ukur $20 \mathrm{~mL}$ dan dilarutkan dengan $20 \mathrm{~mL}$ etanol $96 \%$. Sehingga akan mendapatkan larutan sampel ekstrak seledri dengan konsentrasi $200 \mathrm{mgL}^{-1}$. Larutan diukur absorbansinya menggunakan spektrofotometri UV-Vis pada panjang gelombang $269 \mathrm{~nm}$. Pengukuran dilakukan sebanyak 5 kali pengulangan.

\section{HASIL DAN PEMBAHASAN \\ Pembuatan ekstrak seledri}

Ekstrak seledri diekstraksi menggunakan metode maserasi. Pelarut yang digunakan adalah etanol 96\%. Pemilihan pelarut berdasarkan kelarutan senyawa apigenin. Apigenin merupakan senyawa yang bersifat polar, etanol diharapkan dapat menarik senyawa apigenin di dalam seledri. Hasil maserasi dengan menggunakan pelarut etanol $96 \%$ menghasilkan rendemen ekstrak seledri sebesar $10,47 \%$ (356 gram).

Rendemen ekstrak yang dihasilkan sangat kecil yaitu 10,47\%, hal ini disebabkan karena saat melakukan pengeringan ekstrak menggunakan freeze dry banyak ekstrak yang menempel dalam tabung. Sehingga mengurangi jumLah ekstrak kering yang dihasilkan.

\section{Uji flavonoid}

Apigenin merupakan salah satu senyawa golongan flavonoid. Dari hasil uji flavonoid, ekstrak seledri memberikan hasil yang positif dimana menghasilkan warna kuning yang dapat ditarik oleh amil alkohol.

\section{Analisis Apigenin Menggunakan Kromatografi Lapis Tipis (KLT)}

Apigenin dalam ekstrak seledri dianalisis menggunakan Kromatografi Lapis Tipis (KLT) dengan fase gerak berupa perbandingan pelarut kloroform : metanol $(9,5: 0,5)$ dan fase diam lempeng silika gel $\mathrm{GF}_{254}$.

Adanya senyawa apigenin dalam sampel dapat dibuktikan dengan membandingkan nilai $R_{f}$ bercak ekstrak (kiri) dengan $\mathrm{R}_{\mathrm{f}}$ standar (kanan). Nilai $\mathrm{R}_{\mathrm{f}}$ yang sama atau berdekatan dari suatu bercak menandakan keberadaan senyawa yang dimaksud. Pada Gambar 2, dapat dilihat adanya bercak nomor 3 dari sampel ekstrak seledri (kiri) yang muncul berdekatan dengan bercak dari apigenin standar (kanan). Hal ini mengindikasikan bahwa dalam sampel ekstrak seledri mengandung senyawa apigenin. Adanya bercak lain pada lempeng menunjukkan senyawa lain yang terdapat pada ekstrak tersebut. Nilai $R_{\mathrm{f}}$ apigenin yang didapat adalah 0,75 dengan bercak berwarna ungu. Gambar hasil analisis KLT dapat dilihat pada Gambar 2. 


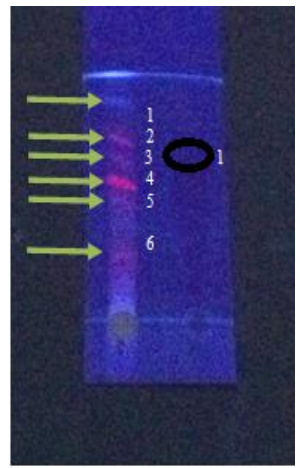

UV $365 \mathrm{~nm}$

Gambar 2. Uji KLT ekstrak seledri (kiri) dan apigenin standar (kanan) dengan fase gerak kloroform : metanol $(9,5: 0,5)$ dan fase diam lempeng silika gel $\mathbf{G F}_{254}$

\section{Penentuan panjang gelombang serapan maksimum ( $\lambda$ max) Apigenin}

Panjang gelombang maksimum adalah panjang gelombang dimana suatu zat memiliki nilai absorbansi terbesar. Dipilih panjang gelombang maksimum karena pada panjang gelombang ini akan menghasilkan respon yang paling maksimum. Nilai panjang gelombang maksimum dapat digunakan juga sebagai identifikasi kualitatif, karena bersifat spesifik. Oleh karena itu panjang gelombang maksimum dapat mewakili parameter selektivitas.

Pada penetapan panjang gelombang maksimun larutan apigenin standar menggunakan pelarut etanol 96\% sebanyak 5 kali pengulangan, didapatkan absorbansi maksimum pada panjang gelombang $269 \mathrm{~nm}$. Hasil selengkapnya dapat dilihat pada Tabel I.

Tabel I. Hasil uji penentuan panjang gelombang serapan maksimum ( $\lambda$ max) apigenin

\begin{tabular}{ccc}
\hline Replikasi & $\begin{array}{c}\lambda \mathbf{m a x} \\
(\mathbf{n m})\end{array}$ & $\begin{array}{c}\text { Rata-rata } \\
(\mathbf{n m})\end{array}$ \\
\hline 1 & 269 & \\
2 & 269 & \\
3 & 270 & 269 \\
4 & 269 & \\
5 & 268 & \\
\hline
\end{tabular}

Pada Farmakope Herbal Indonesia, identifikasi apigenin dilakukan pada panjang gelombang maksimum $269 \mathrm{~nm}$. Hal ini menunjukan bahwa hasil yang didapat sudah sesuai karena menghasilkan panjang gelombang maksimum yang sama.

\section{Validasi metode analisis}

\section{Sensitivitas}

Penetapan nilai ekstingsi molar $(\varepsilon)$ apigenin dilakukan pada tiga variasi konsentrasi yaitu 2, 4, dan $6 \mathrm{mgL}^{-1}$ pada panjang gelombang maksimum apigenin $269 \mathrm{~nm}$. Nilai ekstingsi molar dari apigenin yang diperoleh pada penelitian ini yaitu memiliki rata-rata sebesar $77.004,35 \mathrm{M}^{-1} . \mathrm{cm}^{-1}$. Nilai yang dihasilkan dari perhitungan ekstingsi molar apigenin lebih besar dari $10.000 \mathrm{M}^{-1} . \mathrm{cm}^{-1}$ yang menunjukkan bahwa sistem kromofor apigenin cukup baik dan dapat dianalisis secara kuantitatif menggunakan spektrofotometri UV (AOAC, 1990). 


\section{Linearitas}

Uji linearitas dilakukan untuk melihat kemampuan suatu alat memberikan respon yang baik dan menghasilkan hasil pengujian yang sebanding dengan kadar analit. Parameter yang ditentukan dari uji linearitas adalah koefisien korelasi. Nilai koefisien korelasi berbanding lurus dengan linearitas konsentrasi dengan absorbansi yang dihasilkan. Untuk mengetahui hubungan linearitas antara konsentrasi dengan absorbansi maka dibuat kurva kalibrasi dari Apigenin Standar. Kurva kalibrasi dibuat dengan cara mengencerkan larutan baku standar menjadi 2, 4, 6, 8, dan $10 \mathrm{mgL}^{-1}$. Pengukuran dilakukan sebanyak tiga kali pengulangan. Persamaan kurva kalibrasi didapatkan dengan memplot konsentrasi pada sumbu $\mathrm{x}$ dan absorbansi pada sumbu y. Persamaan garis yang didapatkan dari hasil pengujian kurva kalibrasi dapat dilihat pada Gambar 2.

Salah satu syarat metode analisis dikatakan valid menurut Harmita (2004) dan Synder et al. (1997) adalah nilai koefisien korelasinya $\geq 0,999$. Nilai koefisien korelasi yang semakin mendekati angka 1 menandakan bahwa suatu kurva kalibrasi menghasilkan garis yang linear dan kesalahan yang dapat terjadi antara 2 variabel yang berhubungan (absorbansi dan konsentrasi) semakin kecil. Nilai koefisien korelasi yag dihasilkan berdasarkan rasio serapan terhadap konsentrasi menunjukkan nilai 0,9996. Hal ini membuktikan bahwa metode analisis yang digunakan telah memenuhi syarat linearitas pada rentang konsentrasi $2 \mathrm{mgL}^{-1}$ sampai $10 \mathrm{mgL}^{-1}$.

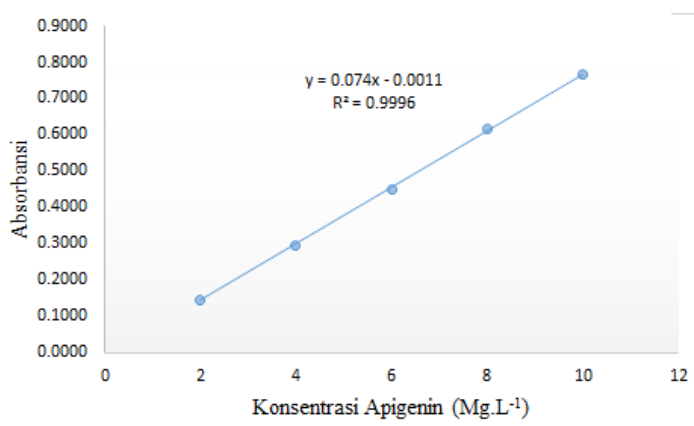

Gambar 3. Kurva kalibrasi apigenin standar konsentrasi 2, 4, 6, 8, dan $10 \mathrm{mgL}^{-1}$

\section{Batas deteksi dan batas kuantifikasi}

Batas deteksi dan batas kuantifikasi ditentukan berdasarkan persamaan garis hasil uji linearitas. Batas deteksi ditentukan untuk mengetahui konsentrasi terkecil yang digunakan agar tetap memberikan kecermatan yang baik yang masih bisa dideteksi oleh instrumen, sedangkan batas kuantifikasi digunakan untuk mengetahui konsentrasi terkecil yang masih memberikan hasil ketelitian yang akurat.

Batas kuantifikasi dipengaruhi oleh galat sistemik yang ditunjukkan oleh intersep pada persaman garis. Pendekatan yang dilakukan untuk menentukan nilai batas kuantifikasi sama dengan pendekatan yang dilakukan untuk menentukan batas deteksi. Hanya saja batas kuantifikasi sering dianggap memiliki perbandingan sebesar 10:1 terhadap signal-to-noise ratio, sedangkan batas deteksi memiliki nilai dengan perbandingan sebesar 3:1 untuk signal-to-noise ratio.

Nilai Batas deteksi yang didapat adalah $2,99 \mathrm{mgL}^{-1}$ dan nilai Batas kuantifikasi yang didapat adalah $9,92 \mathrm{mgL}^{-1}$. Nilai Batas deteksi dan Batas kuantifikasi berbeda-beda tergantung pada metode yang digunakan. Persamaan garis yang digunakan adalah persamaan garis rata-rata dari uji linearitas. Jika analit memberikan sinyal lebih rendah daripada nilai Batas deteksi dan Batas kuantifikasi, maka kecermatan dan ketelitian yang dihasilkan kurang baik.

\section{Akurasi dan presisi}

Akurasi adalah derajat kedekatan perhitungan hasil analisis terhadap analit yang sebenarnya atau juga dikenal dengan persen recovery. Menurut Harmita (2004) suatu metode dinyatakan akurat apabila range nilai persen recovery sebesar $90-110 \%$. Selain itu konsentrasi yang digunakan harus mewakili rentang konsentrasi kurva baku (ICH, 2005). Presisi diukur sebagai koefisien variasi (KV), 
ditentukan untuk mengetahui kesalahan yang terjadi pada proses analisis. Presisi menunjukkan nilai ketelitian suatu metode ketika dilakukan oleh analisis dan kondisi yang sama pada interval waktu yang pendek (Harmita, 2004). Suatu metode dikatakan memenuhi kriteria presisi jika persen KV < $2 \%$.

Akurasi dan Presisi dimaksudkan untuk meningkatkan keakuratan dan kevalidan dari suatu metode analisis dengan cara menambahkan standar apigenin kedalam sampel ekstrak seledri (standart addition). Dengan adanya penambahan standar apigenin kedalam sampel akan lebih menguatkan keberadaan senyawa apigenin dalam sampel ekstrak seledri.

Nilai rata-rata persen recovery yang didapatkan adalah sebesar 97,59\% dengan persen CV masing-masing sebesar $1,53 \%, 2,43 \%$, dan $1,68 \%$. Hal ini menunjukkan bahwa metode yang digunakan telah memenuhi kriteria akurasi dan presisi. Besarnya toleransi nilai persen recovery sangat bergantung pada konsentrasi sampel atau analit yang diukur.

\section{Uji kadar apigenin dalam ekstrak seledri}

Uji kadar apigenin dalam ekstrak seledri dilakukan untuk mengetahui seberapa besar kadar apigenin di dalam ekstrak seledri. Konsentrasi akhir didapatkan dari hasil perhitungan menggunakan persamaan garis $\mathrm{y}=0,074 \mathrm{x}-0,0011$. Penentuan absorbansi dilakukan sebanyak lima kali pengulangan. Dari hasil pengujian kadar, didapatkan kadar apigenin dalam ekstrak seledri sebesar 3,74 $\%$ (v/v). Hasil penetapan kadar apigenin dalam ekstrak seledri dapat dilihat pada Tabel III

Tabel II. Hasil validasi metode analisis

\begin{tabular}{ccc}
\hline Parameter & Syarat & Hasil \\
\hline Sensitivitas (Nilai ekstingsi molar) & $>10.000 \mathrm{M}^{-1} \cdot \mathrm{cm}^{-1}$ & $77.004,35 \mathrm{M}^{-1} \cdot \mathrm{cm}^{-1}$ \\
Linieritas (Nilai R) & $>0,999$ & 0,9996 \\
Limit of Detection (LOD) & - & $2,99 \mathrm{mgL}^{-1}$ \\
Limit of Quantification (LOQ) & - & $9,92 \mathrm{mgL}^{-1}$ \\
Akurasi (\% Recovery) & $97,59 \%$ & $90-110 \%$ \\
Presisi (\% Koevisien Variasi) & $<2 \%$ & $1,53 \% ; 2,43 \% ; 1,68 \%$ \\
\hline
\end{tabular}

Tabel III. Kadar apigenin dalam ekstrak seledri

\begin{tabular}{cccc}
\hline Replikasi & Absorbansi & $\begin{array}{c}\text { Kadar } \\
\left(\mathbf{m g L}^{-1}\right)\end{array}$ & $\begin{array}{c}\text { Kadar (\%) } \\
(\mathbf{v} / \mathbf{v})\end{array}$ \\
\hline 1 & 0,5660 & 7,66 & 3,83 \\
2 & 0,5616 & 7,60 & 3,80 \\
3 & 0,5378 & 7,28 & 3,64 \\
4 & 0,5577 & 7,55 & 3,78 \\
5 & 0,5407 & 7,32 & 3,66 \\
\hline \multicolumn{2}{l}{ Rata-rata kadar \pm SD $(\%)$} & & $3,74 \pm 0,09$ \\
\hline
\end{tabular}

\section{KESIMPULAN}

Berdasarkan hasil penelitian yang sudah dilakukan, dapat disimpulkan bahwa metode analisis yang akan digunakan memenuhi persyaratan-persyaratan parameter validasi seperti sensitivitas, linearitas, batas deteksi, batas kuantifikasi, akurasi, dan presisi.

\section{UCAPAN TERIMAKASIH}

Terima kasih disampaikan kepada Rektor Universitas Padjadjaran yang telah mendukung pendanaan penelitian ini melalui program hibah Academic Leadership Grant (ALG).

\section{DAFTAR PUSTAKA}

Andrea, K., Katja, I.H., Dietmar, R.K., dan Reinhold, C. 2013. Evaluation of The Effects of Thermal Treatments on Color, Polyphenol Stability, Enzyme Activities and Antioxidant Capacities of 
Innovative Pasty Celeriac (Apium graveolens L. Var. Rapaceum (Mill.) DC.) Products. European Food Research and Technology, 237(3): 353-365.

Agoes, A. 2010. Tanaman Obat Indonesia. Jakarta : Salemba Medika.

Al-snafi, A.E. 2014. The Pharmacology of Apium graveolens - A Review. International Journal for Pharmaceutical Research Scholars; 3(1): 671-677.

AOAC. 1990. Official Methods of Analisis. Association of Official Analitycal Chemist. Washington DC : United State of America.

Arzi, A., Hemmati, A.A., Karampour, N.S., Nazari, Z., dan Baniahmad, B. 2014. Anti-inflamatory Effect of Celedry Seed Hydroalcoholic Extract on Carrageenan-Induced Paw Edema in Rats. Research Journal of Pharmaceutical, Biological and Checimal Sciences, 5(6): 24-29.

BPOM RI. 2008. Seledri (Apium graveolans L.) Sebagai Bahan Obat Alam. Jakarta : Badan Pengawas Obat dan Makanan Republik Indonesia.

Boyong, L., Dennis, H.R., dan Diane, F.B. 1997. Evaluation of Properties of Apigenin and [G${ }^{3}$ H]Apigenin and Analytic Method Development. Journal of Pharmaceutical Sciences, 86(6): 721-725.

Choi, E.J dan Kim, G.H. 2009. Apigenin causes $\mathrm{G}_{2} / \mathrm{M}$ arrest associated with the modulation of $\mathrm{p} 21^{\text {cop } 1}$ and $\mathrm{Cdc} 2$ and activates p53-dependent apoptosis pathway in human breast cancer SK-BR-3 cells. The Journal of Nutritional Biochemistry, 20(4): 285-90.

Ellin, F., Eli, H., dan Sri, A.S. 2009. Aktivitas Antihiperlipidemia Ekstrak Etanol Herba Seledri (Apium graveolens L.) Dari Daerah Bandung Barat. Bandung : Fakultas Farmasi Universitas Padjadjaran.

Harborne, J.B. 1987. Metode Fitokimia. Penerjemah : Padmawinata K dan Soediro I, Edisi II. Bandung : Institut Teknologi Bandung - Press.

Harmita. 2004. Petunjuk Pelaksanaan Validasi Metode dan Cara Perhitungannya. Majalah Ilmu Kefarmasian I : 117-135.

Hidayat, A. 1999. Validasi Metode Analisis Kimia. Bul. Agro Bio, 20(2): 49-51

ICH - International Conference on Harmonisation of Technical Requirements for Registration of Pharmaceutical for Human Use. 2005. ICH Harmonised Tripartite Guideline Validation of Analytical Procedures: Text and Methodology Q2 (R1).

Rahma, J.Z. 2008. Validasi Metode Penentuan Kadar Apigenin Dalam Ekstrak Seledri Dengan Kromatografi Cair Kinerja Tinggi. Bogor : Institut Pertanian Bogor.

Siladitya, B., Subhajit, G., Fahad, A., Saayak, S., dan Sritoma, B. 2012. UV-Visible Spectrophotometric Method Development and Validation of Assay of Paracetamol Tablet Formulation. Journal of Analytical \& Bioanalytical Techniques, 3(6): 1-6.

Shukla, S dan Gupta, S. 2008. Apigenin Induced Pristate Cancer Cell Death is Initiated bt Reactive Oxygen Species and p54 Activation. Journal Free Radical Biology and Medicine, 44(10): 18331845.

Synder, L.R., Kirkland, J.J., dan Glajch, J.L. 1997. Practical HPLC Method Development $2^{\text {nd }}$ Edition. New York : John Willey \& Sons, Inc.

Vergara, G.J., Jimenez, R.L.Á., Tun, S.A., Aguirre, C.F., Salazar, G.A., Estrada, S.S., Sierra, O.Á., dan Hernandez, N.E. 2013. Vasorelaxant Activity of Extracts Obtained From Apium graveolens : Possible Source For Vasorelaxant Molecules Isolation With Potential Antihypertensive Effect. Asian Pacific Journal of Tropical Biomedicine; 3(10): 776-779.

Vidya, D., Dhanashri, M., dan Neeta, S. 2011. High Performance Liquid Chromatographic Method For Quantization of Apigenin From Dried Root Powder of Gmelina arborea Linn. International Journal of Pharma and Bio Sciences, 2(1): 742-749.

Zsófia, E.P., Zita, S., Krisztina, L., Nikolett, K., Emese, B., Annamária, K., Satyanarayana, S., Béla, B., dan István, A. 2016. Comparative Evaluation of The Effect of Cyclodextrins and $\mathrm{pH}$ on Aqueous Solubility of Apigenin. Journal of Pharmaceutical and Biomedical Analysis, 117: 210-216. 
